\title{
Penanganan Sedimentasi di Pelabuhan Tanjung Api-Api pada Sungai Banyuasin Provinsi Sumatera Selatan
}

\author{
KEN WIRALINO TAREDJA, EKA OKTARIYANTO NUGROHO \\ Jurusan Teknik Sipil, Institut Teknologi Nasional, Bandung \\ Email: kwiralino@gmail.com
}

\begin{abstract}
ABSTRAK
Penumpukan sedimentasi adalah salah satu permasalahan yang dihadapi oleh terminal pelabuhan. Terminal pelabuhan dituntut memberikan fasilitas sarana dan prasarana serta pelayanan sebaik-baiknya agar sesuai dengan Peraturan Menteri Perhubungan Republik Indonesia Nomor 51 Tahun 2015 tentang Penyelenggaraan Pelabuhan Penyebrangan. Tujuan dari penelitian ini adalah untuk mengetahui penanganan sedimentasi yang terjadi pada Pelabuhan Tanjung Api-Api. Sedimentasi yang terjadi pada Pelabuhan Tanjung Api-Api dihitung dengan perhitungan numerik menggunakan aplikasi MIKE 21. Data yang digunakan adalah data sekunder berupa batimetri, pasang surut, gelombang, dan debit. Dari hasil pemodelan didapatkan penumpukan sedimentasi pada pelabuhan penyebrangan sebesar 0,24 m dalam 3 bulan dan dipilih penanganan dengan cara melakukan pengerukan alur hingga $-5 \mathrm{~m}$.
\end{abstract}

Kata kunci: pelabuhan, sedimentasi, alur

\begin{abstract}
Sedimentation is one of the problems in the port terminals. Port terminals are required to provide facilities, infrastructure and services as written in the regulation PM 512015 on the Port Distribution Port. This research aims to explore how to deal with the sedimentation at Tanjung Api-Api Port. Sedimentation that at Tanjung Api-Api Port was calculated by numerical calculation using MIKE 21 application. The data input for numerical model is used form previous study. The input data are bathimetry, tidal, wave, and discharge. The computation shows than the dredging channel by $-5 \mathrm{~m}$ is proven to be the best design among afters scenario. The calculation of sedimentation depth is similar as primary data and has acknowledge 0,24 in 3 month.
\end{abstract}

Keywords: port, sedimentation, channel 


\section{PENDAHULUAN}

Pelabuhan adalah daerah perairan yang dilengkapi dengan fasilitas terminal laut meliputi dermaga dimana kapal dapat bertambat untuk bongkar muat barang, naik turun penumpang. Terminal ini dilengkapi dengan fasilitas keselamatan dan keamanan pelayaran dan kegiatan penunjang pelabuhan serta berbagai tempat perpindahan intra-dan antarmoda transportasi. Pelabuhan Tanjung Api-Api merupakan suatu pelabuhan yang berada di suatu tanjung pada posisinya di pesisir daerah laut. Saat ini operasional pelabuhan mengalami kendala dalam hal pergerakan kapal menuju area dermaga dimana alur yang ada dianggap tidak mencukupi bagi kapal untuk lewat dalam tujuannya untuk bersandar ke dermaga.

Tujuan dari penelitian ini adalah untuk melakukan pembuatan desain profil alur pelayaran pelabuhan yang sesuai dengan Peraturan Menteri Perhubungan Republik Indonesia Nomor 51 Tahun 2015 tentang Penyelenggaraan Pelabuhan Penyebrangan. Secara khusus, terdapat beberapa ruang lingkup dalam penelitian ini, obyek strudi yang ditinjau adalah Pelabuhan Tanjung Api-Api, penggunaan data dari data sekunder mengenai batimetri, pasang surut, gelombang, dan debit. Pemodelan pola sedimentasi menggunakan aplikasi MIKE 21 dengan beberapa skenario penanganan.

\section{TINJAUAN PUSTAKA}

\subsection{Pasang Surut}

Menurut Triatmodjo, B. (2009) pasang surut adalah fluktuasi muka air laut sebagai fungsi waktu karena adanya gaya tarik benda-benda di langit, terutama matahari dan bulan terhadap massa air laut di bumi. Massa bulan jauh lebih kecil dari massa matahari, tetapi karena jaraknya terhadap bumi jauh lebih dekat, maka pengaruh gaya tarik bulan terhadap bumi lebih besar daripada pengaruh gaya tarik matahari.

Bentuk pasang surut di berbagai daerah tidak sama. Satu hari dapat terjadi satu kali atau dua kali pasang surut di suatu daerah. Secara umum tipe pasang surut di berbagai daerah dapat dibedakan menjadi empat tipe antara lain pasang surut harian ganda (semi diurnal tide), pasang surut harian tunggal (diurnal tide), pasang surut campuran condong ke harian ganda (mixed tide prevailing semidiurnal), pasang surut campuran condong ke harian tunggal (mixed tide prevailing diurnal).

\subsection{Gelombang}

Menurut Triatmodjo, B. (2009) gelombang dilaut biasa dibangitkan oleh angin (gelombang angin), gaya tarik matahari dan bulan (pasang surut), letusan gunung berapi atau gempa dilaut (tsunami), kapal bergerak dan sebagainya. Bentuk gelombang tersebut yang paling penting dalam perencanaan pelabuhan adalah gelombang angin dan pasang surut. Gelombang tersebut akan menimbulkan gaya-gaya yang bekerja pada bangunan pelabuhan. Gelombang juga bisa menimbulkan arus dan transpor sedimen di daerah pantai. Tata letak/layout pelabuhan harus direncanakan sedemikian rupa sehingga sedimentasi di pelabuhan dapat dikurangi/dihindari.

\subsection{Debit}

Menurut Soemarto (1987) debit adalah volume air yang mengalir per satuan waktu melewati suatu penampang melintang palung sungai, pipa, pelimpah, akuifer dan sebagainya. Debit sungai berubah-ubah menurut waktu. Angka sekian $\mathrm{m}^{3} /$ detik menunjukkan debit sesaat pada 
suatu pos pengukur debit. Hidrograf adalah penyajian secara grafis variasi debit menurut waktu. Dari hidrograf tersebut kita dapat mengtahui berapa besar volume air yang melewati pos pengukut debit dalam suatu waktu tertentu.

\subsection{Perangkat Lunak MIKE 21}

MIKE 21 adalah pemodelan terhadap pesisir dan perairan laut. Memasukkan data-data pendukung seperti data batimetri, data pasang surut, data arus, data sungai, dan besar sedimen yang terdapat di wilayah tersebut, maka akan didapatkan hasil tinggi muka air yang terjadi, kecepatan arus, debit, dan sedimentasi yang terjadi dalam jangka waktu tertentu. Modul yang digunakan pada MIKE 21 adalah Flow Model.

Penelitian ini menggunakan MIKE 21 Flow Model, dengan modul Hydrodynamic (HD) dan modul Mud Transport (MT). MIKE 21 modul Hydrodynamic adalah model matematik untuk menghitung perilaku hidrodinamika air terhadap berbagai macam fungsi gaya, sebelumnya sudah ditentukan di open model boundaries. Modul HD ini mensimulasi perbedaan tinggi muka air dan arus dalam menghadapi berbagai fungsi gaya di danau, estuari, dan pantai.

\section{METODE PENELITIAN}

\subsection{Lokasi Pengamatan}

Lokasi penelitian berada di Pelabuhan Tanjung Api-Api, Sumatera Selatan dengan koordinat $2^{\circ} 22^{\prime} 23.20^{\prime \prime}$ Lintang Selatan 10448'20.18" Bujur Timur yang ditunjukkan pada Gambar 1.

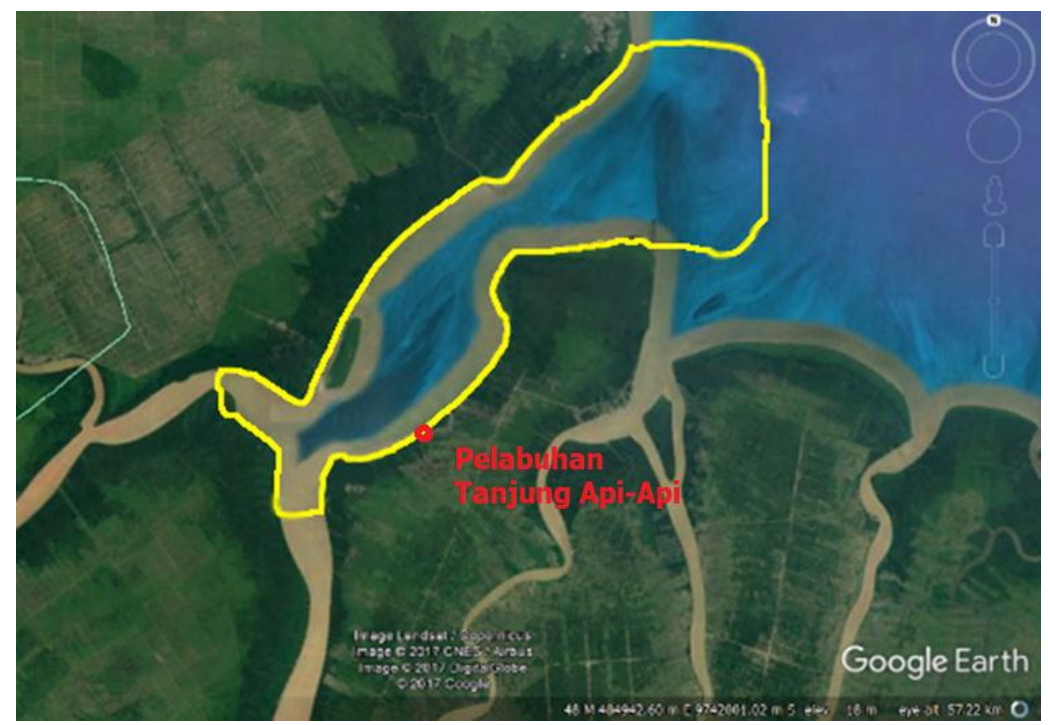

Gambar 1. Lokasi pengamatan

(Sumber: Centre National d'Etudes Spatiales, 2018)

\subsection{Data Penelitian}

Data sekunder yang digunakan merupakan data yang didapatkan deangan cara menghubungi instansi yang terkait dengan perencanaan proyek. Data ini terdiri dari data batimetri yang didapatkan dari hasil survey PT. ATLAS seperti pada Gambar 2, data pasang surut didapatkan dari hasil survey PT. ATLAS seperti pada Gambar 3, data gelombang merupakan hasil pengolahan data angin yang didapatkan dari National Oceanic and Atmospheric Administration yang diolah dengan bantuan aplikasi WRPLOT menjadi mawar gelombang seperti disajikan pada Gambar 4, dan data hidrograf debit seperti pada Gambar 5. 


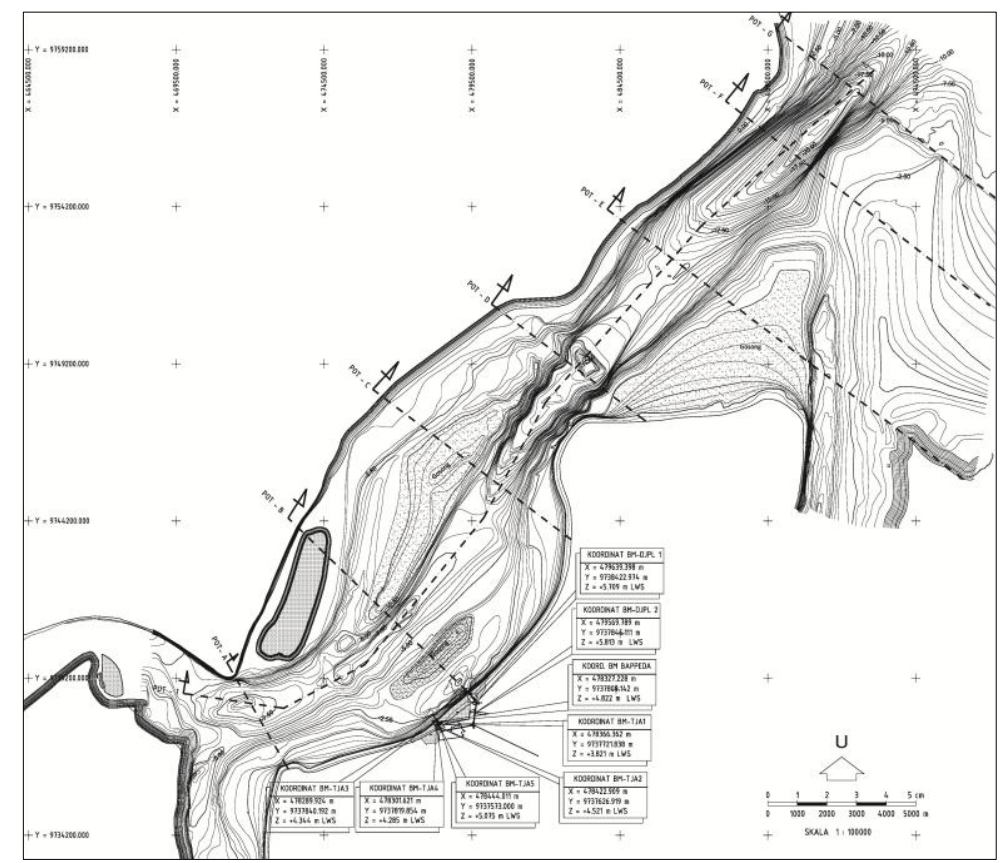

Gambar 2. Batimetri lokasi pengamatan (Sumber: PT. ATLAS, 2016)

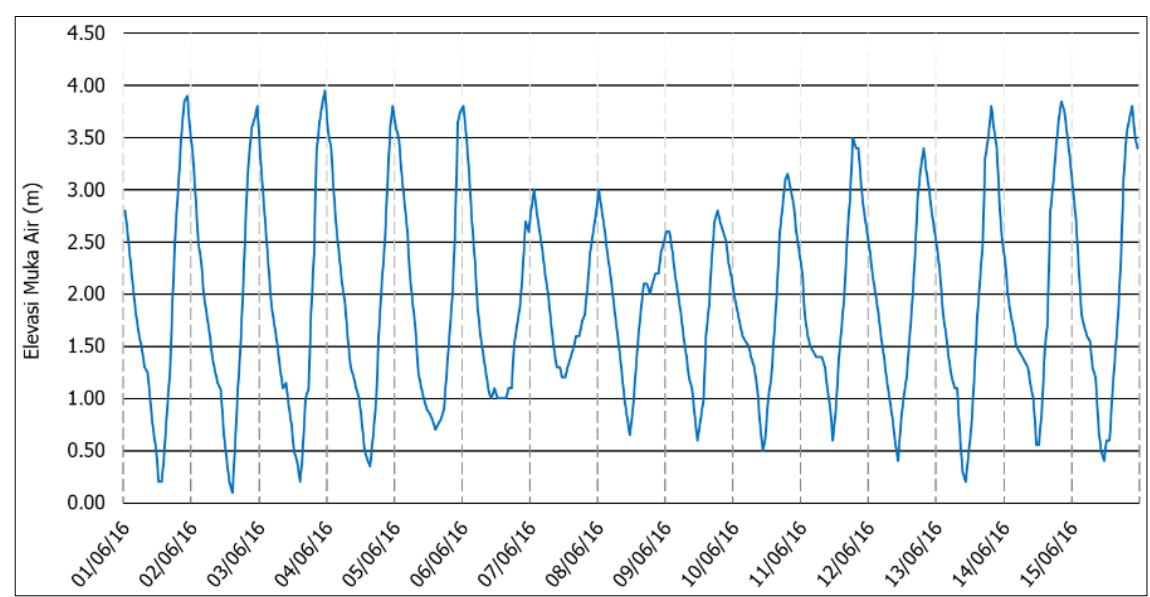

Gambar 3. Pengamatan pasang surut Muara Banyuasin selama 15 hari (Sumber: PT. ATLAS, 2016)

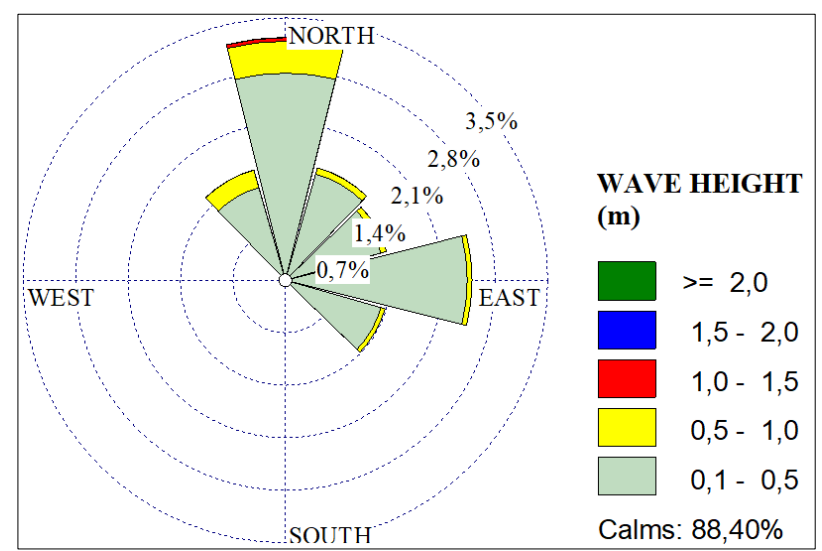

Gambar 4. Mawar gelombang 10 tahun di Muara Banyuasin (Sumber: National Oceanic and Atmospheric Administration, 2016) 


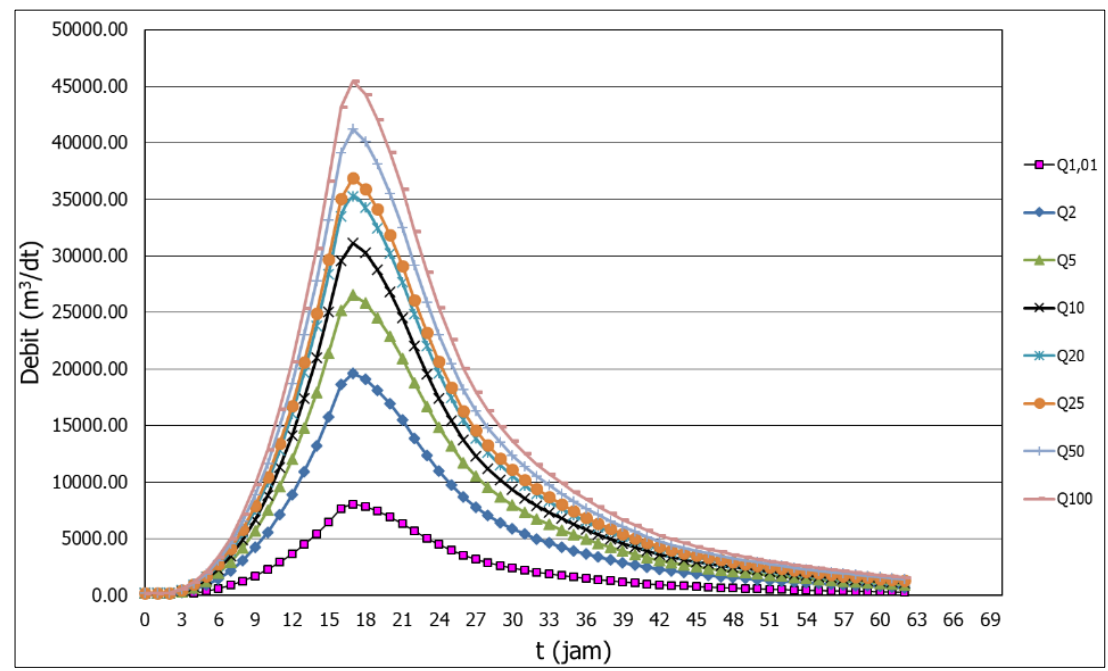

Gambar 5. Debit hidrograf Sungai Lilin

\subsection{Alur penelitian}

Analisis pendahuluan dilakukan dengan mengolah data-data yang diperlukan seperti batimetri. Batimetri yang digunakan pada penelitian ini terdiri dari grid series (rectangular) dan mesh generator. Wilayah yang ditinjau merupakan muara yang berada diantara 2 sungai dan laut. Setelah data batimetri sudah ter-digitasi, data tersebut di plot pada grid series MIKE 21. Pemodelan menggunakan mesh generator, data batimetri dalam bentuk .xyz dimasukkan pada modul mesh Generator, lalu data tersebut dihubungkan antar noda menggunakan draw arc. Data batimetri telah memiliki bentuk baru dalam MIKE 21, selanjutnya membuat pemodelan menggunakan flow mode/sehingga dapat diketahui hidrodinamika di wilayah penelitian. Data pasang surut hasil peramalan dan data debit sungai digunakan untuk masukan pada aplikasi MIKE 21.

\subsection{Masukan Aplikasi MIKE 21}

Data sekunder yang didapat, digunakan sebagai masukan untuk aplikasi MIKE 21. Data yang menjadi masukan aplikasi MIKE 21 adalah data batimetri, pasang surut, dan debit sungai. Data batimetri dibuat mesh menggunakan MIKE Zero mesh generator seperti pada Gambar 6 dan hasil pembuatan mesh ditunjukkan pada Gambar 7.

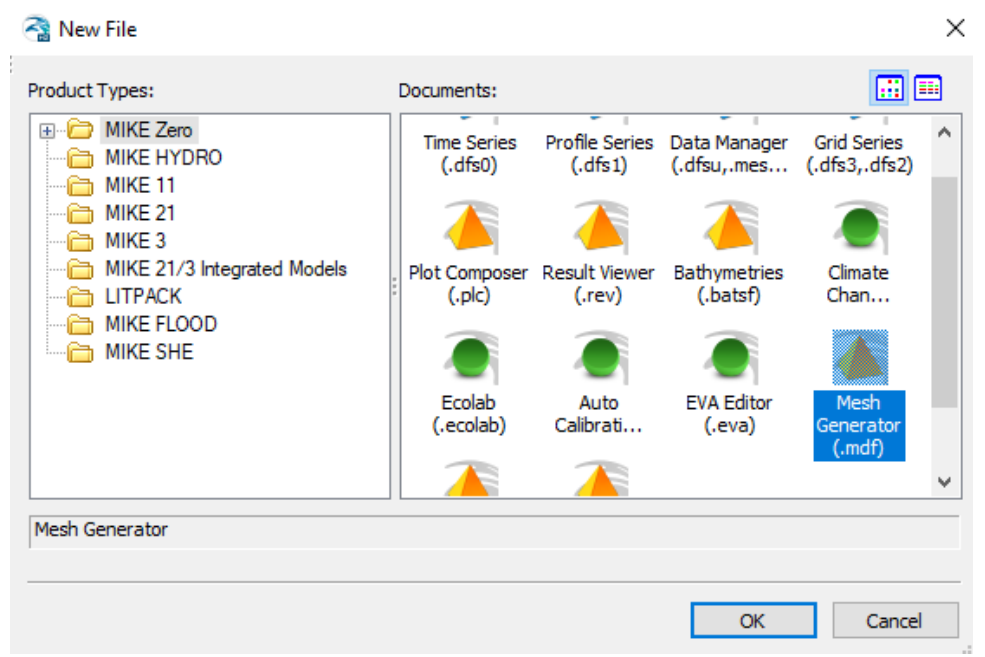

Gambar 6. Mesh Generator 


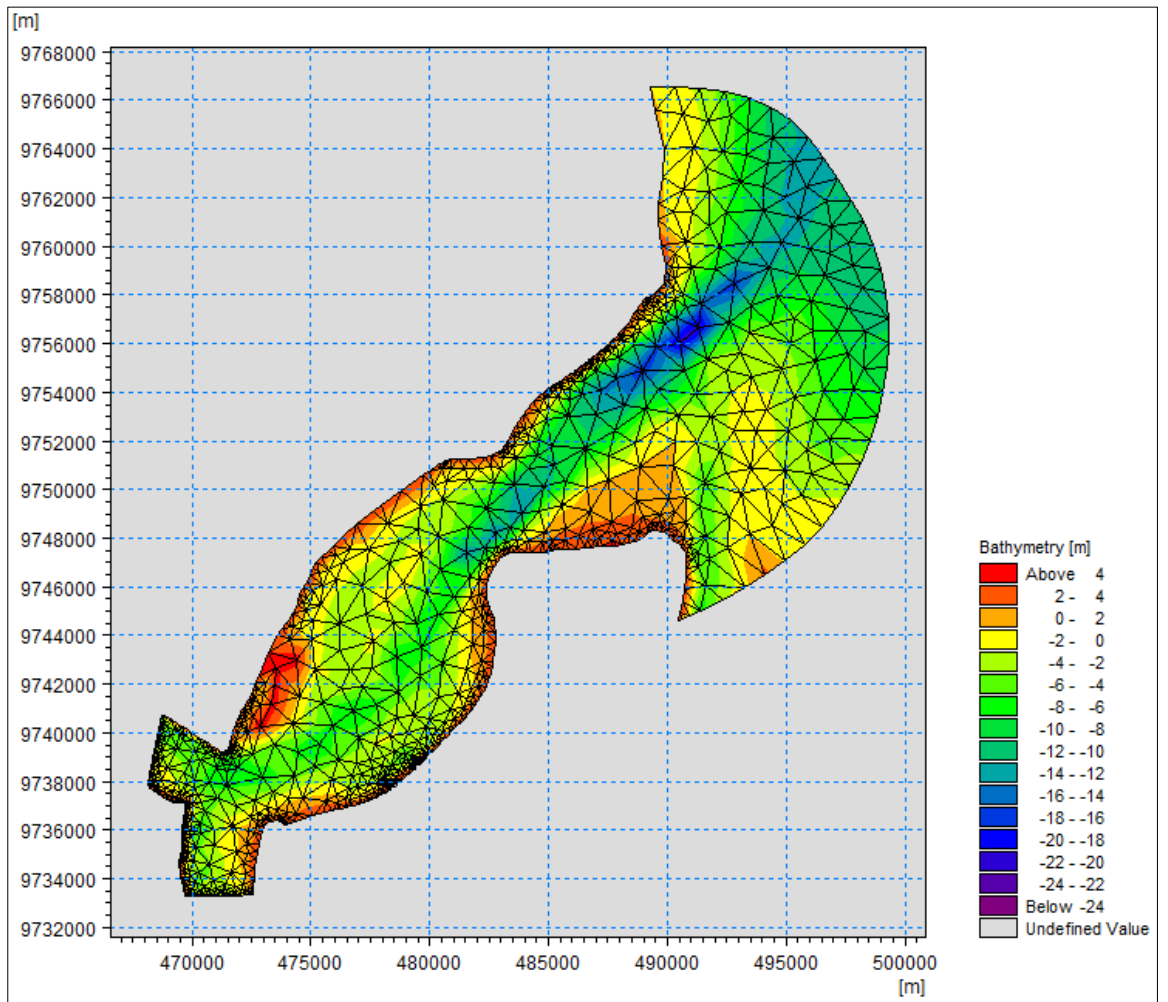

Gambar 7. Mesh lokasi pengamatan

Data Pasang surut hasil pengamatan dan data debit hidrograf dibuat format .dfs0 menggunakan MIKE Zero Time Series seperti pada Gambar 8. Hasil pembuatan time series gelombang pada Gambar 9, hasil pembuatan time series pasang surut pada Gambar $\mathbf{1 0}$ dan hasil pembuatan time series debit sungai pada Gambar 11.

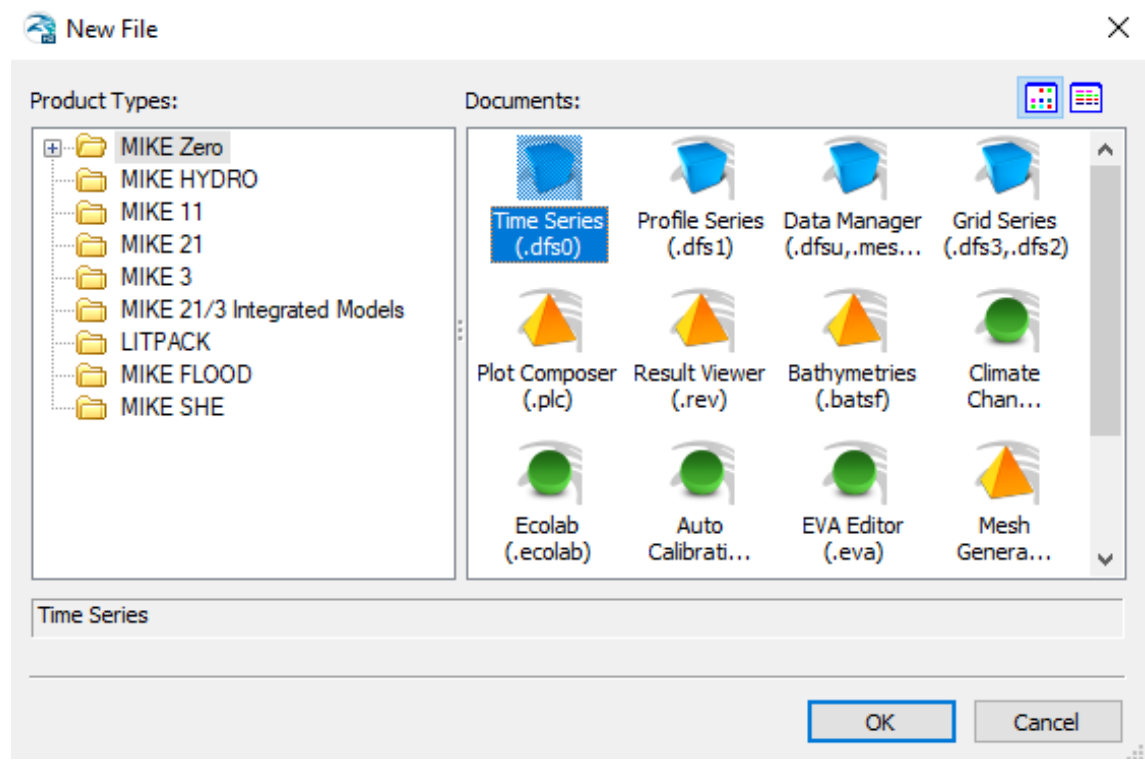

Gambar 8. Time Series 
Penanganan Sedimentasi di Pelabuhan Tanjung Api-Api pada Sungai Banyuasin Provinsi Sumatera Selatan

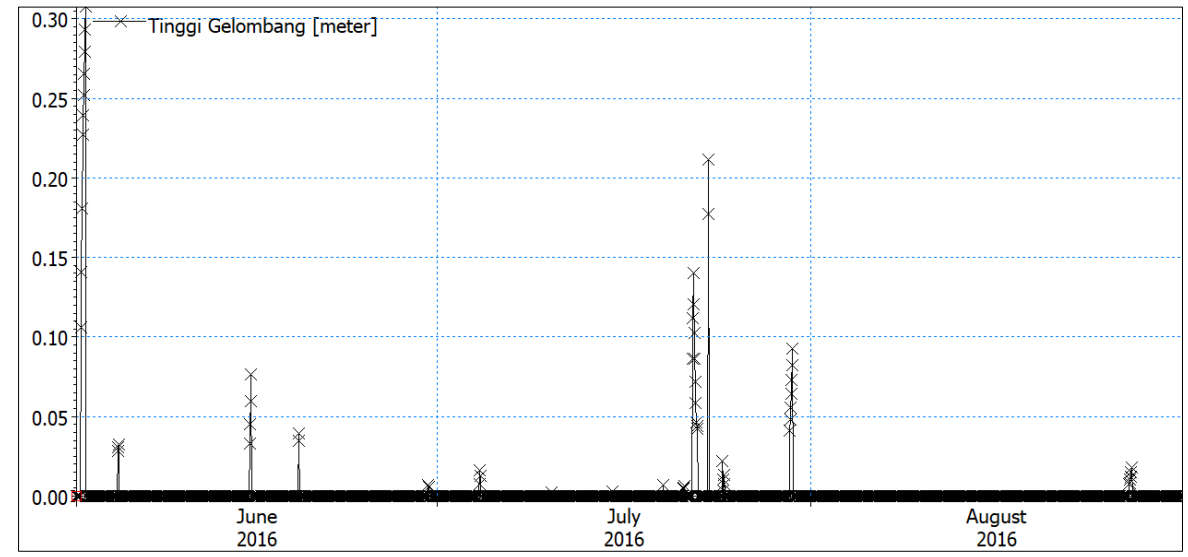

Gambar 9. Gelombang Muara Banyuasin dengan format .dsfo

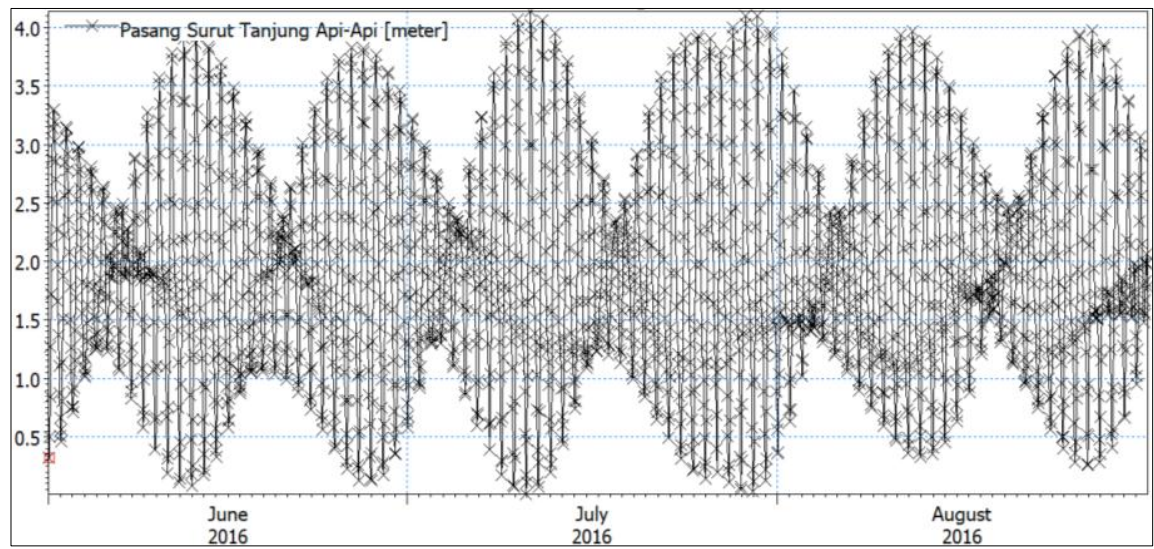

Gambar 10. Pasang surut Muara Banyuasin dengan format .dsfo

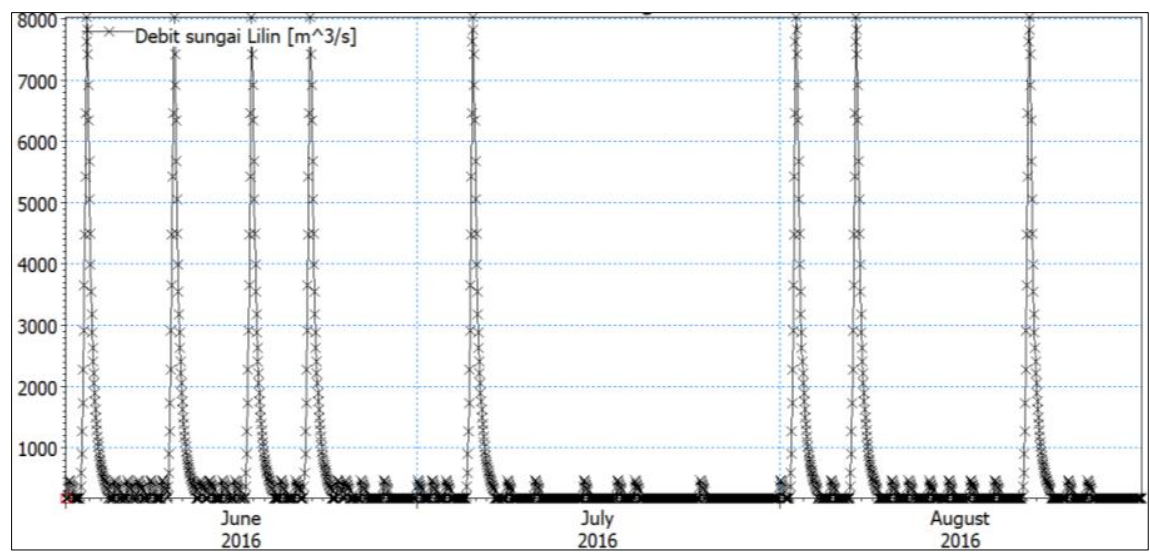

Gambar 11. Debit Sungai Lilin dengan format .dsfo

\section{ANALISIS DAN PEMBAHASAN}

\subsection{Hasil Pemodelan Gelombang Kondisi Eksisting}

Pemodelan gelombang kondisi eksisting dilakukan untuk mengetahui pengaruh gelombang terhadap sedimentasi yang terjadi di daerah sekitar pelabuhan. Hasil pemodelan pola gelombang ditunjukkan pada Gambar 12. 


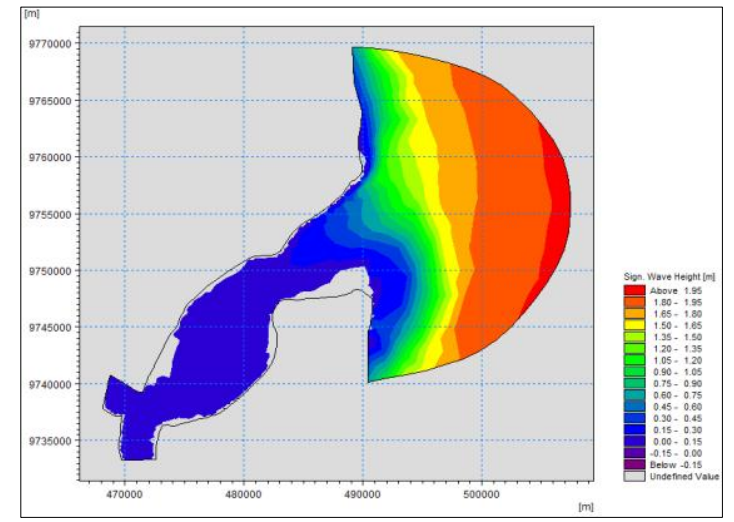

\section{Gambar 12. Hasil pemodelan gelombang di perairan Muara Banyuasin}

Hasil pemodelan gelombang kondisi eksisting di perairan Muara Banyuasin menunjukkan bahwa gelombang tidak berpengaruh membawa sedimentasi ke dalam area pelabuhan, karena tinggi gelombang sekitar area pelabuhan hanya $0,00 \mathrm{~m}$ hingga $0,15 \mathrm{~m}$.

\subsection{Hasil Pemodelan Pola Sedimentasi Kondisi Eksisting}

Pemodelan pola sedimentasi kondisi eksisting dilakukan untuk mengetahui kondisi sedimentasi yang sudah terjadi selama ini. Pemodelan kondisi eksisting dilakukan dengan menggunakan debit konstan dan debit hidrograf. Hasil pemodelan kondisi eksisting dengan jangka waktu 3 bulan ditunjukkan pada Gambar 13 dan Gambar 14.

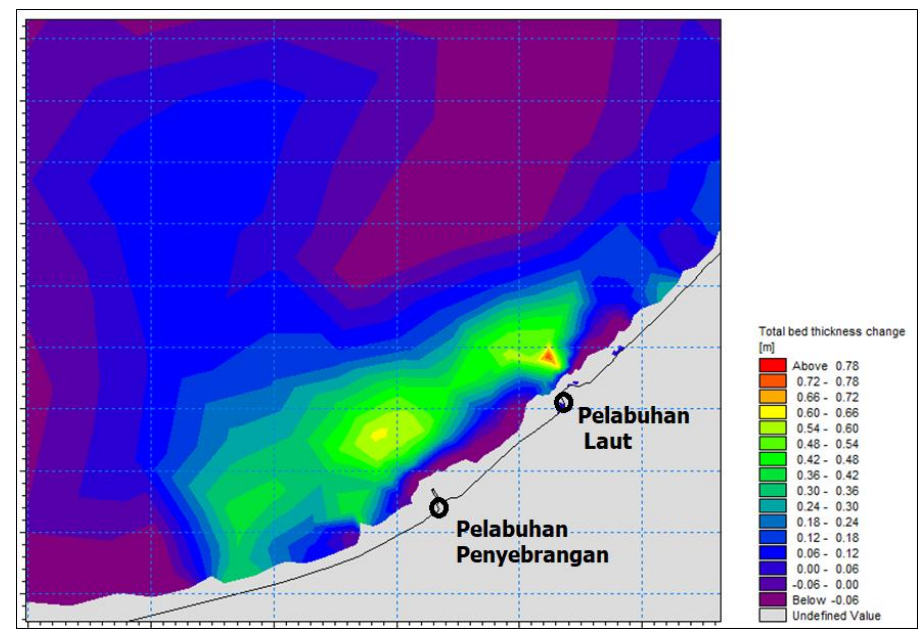

Gambar 13. Ketebalan sedimen kondisi eksisting

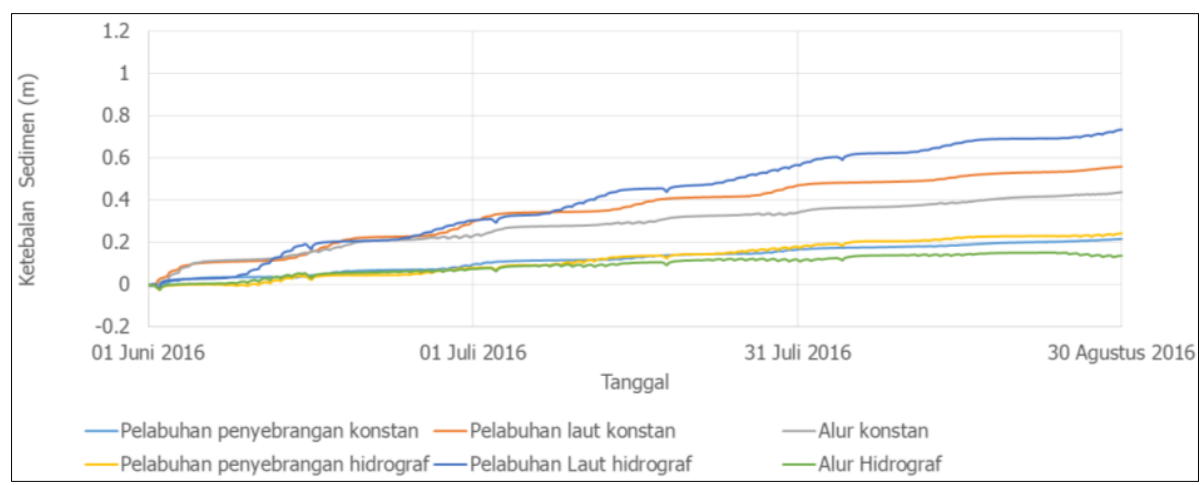

Gambar 14. Grafik ketebalan sedimen kondisi eksisting 
Grafik perbandingan hasil pemodelan kondisi eksisting seperti pada Gambar 14 menunjukkan bahwa hasil pemodelan menggunakan debit hidrograf lebih besar dibandingkan dengan hasil Pemodelan menggunakan debit konstan. Hasil pemodelan debit hidrograf menunjukkan bahwa pada daerah pelabuhan penyebrangan terjadi penumpukan sedimentasi hingga ketinggian 0,24 m dalam 3 bulan sedangkan pada hasil pemodelan dengan menggunakan debit konstan menunjukkan bahwa pada daerah pelabuhan penyebrangan terjadi penumpukan sedimentasi hingga 0,21 m dalam 3 bulan. Hasil pemodelan dengan debit hidrograf digunakan untuk pemodelan skenario penanganan selanjutnya karena memiliki selisih yang lebih kecil dengan kondisi sedimentasi hasil survey yaitu sebesar $0,23 \mathrm{~m}$ dalam 3 bulan.

\subsection{Hasil Pemodelan Pola Sedimentasi Setelah Pengerukan Alur}

Pemodelan setelah pengerukan alur dilakukan untuk mengetahui kondisi sedimentasi jika dilakukan dengan cara pengerukan alur hingga kedalaman $-5 \mathrm{~m}$. Hasil pemodelan setelah dilakukan pengerukan alur ditunjukkan pada Gambar 15.

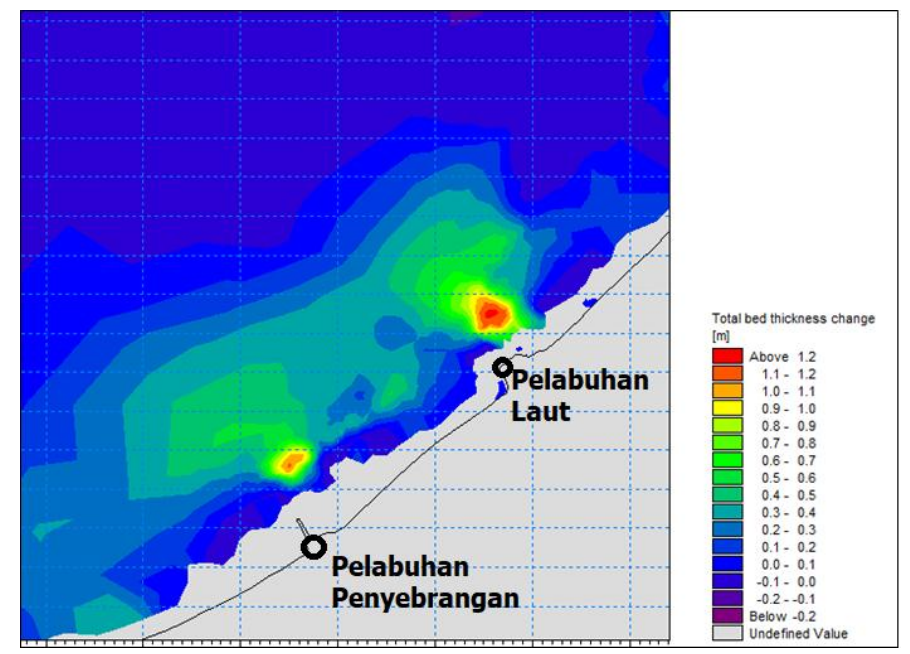

\section{Gambar 15. Ketebalan sedimen setelah dilakukan pengerukan alur}

Hasil pemodelan setelah dilakukan pengerukan alur pada Gambar 15 menunjukkan bahwa ada daerah yang terjadi penumpukan sedimentasi hingga ketinggian 1,2 m dalam 3 bulan, tetapi sebagian besar menunjukkan penumpukan sedimentasi hanya terjadi antara 0,5 m hingga 0,8 $\mathrm{m}$. Penanganan sedimentasi dengan melakukan pengerukan alur hingga kedalaman -5 $\mathrm{m}$ bisa bertahan hingga sekitar 2 tahun jika pola sedimentasi dianggap linier. Penanganan sedimentasi harus dilakukan secara berkala merupakan resiko karena kondisi pelabuhan yang berada di muara dimana sedimen yang terjadi diakibatkan oleh debit sungai dan pasang surut air laut.

\section{KESIMPULAN}

Hasil pemodelan hidrodinamika dan pola sedimentasi yang terjadi di Muara Banyuasin, Sumatra Selatan, ini dapat diambil kesimpulan bahwa gelombang di Muara Banyuasin tidak membawa sedimen ke dalam area pelabuhan karena tinggi gelombang yang terjadi sangat kecil yaitu 0,00 m hingga 0,15 $\mathrm{m}$ dan penumpukan sedimentasi yang terjadi pada hingga ketinggian 0,78 $\mathrm{m}$ dalam kurun waktu 3 bulan. Penumpukan sedimentasi yang terjadi jika dilakukan pengerukan alur hingga ketinggian 1,2 m dalam kurun waktu 3 bulan yang berarti kedalaman alur akan berubah menjadi $-1 \mathrm{~m}$ dalam kurun waktu 2 tahun. Berdasarkan pemodelan penanganan yang digunakan adalah pengerukan alur hingga kedalaman $-5 \mathrm{~m}$ harus dilakukan secara berkala setiap sekitar 2 tahun. 


\section{DAFTAR RUJUKAN}

Centre National d'Etudes Spatiales. (2018, Januari 20). Google. Dipetik Januari 20, 2018, dari Digital Globe. Google Earth Pro: https://www.google.com/maps/@$2.3422007,104.8072885,26755 \mathrm{~m} /$ data $=! 3 \mathrm{~m} 1 ! 1 \mathrm{e} 3$

Kementerian Perhubungan Republik Indonesia. (2015). Peraturan Menteri Perhubungan Republik Indonesia Nomor: 51 Tahun 2015 tentang Penyelenggaraan Pelabuhan Penyebrangan. Jakarta: Kementerian Perhubungan.

National Oceanic and Atmosphiric Administration. (2017, Mei 10). NOAA. Dipetik Mei 10, 2017, dari Earth System Research Laboratory: https://www.esrl.noaa.gov/psd/data/gridded/data.ncep.reanalysis.pressure.html

PT. ATLAS. (2016). Laporan Final Pekerjaan Survey Investigasi dan Desain Alur Pelayaran/Kolam Pelabuhan Tanjung Api-Api Provinsi Sumatera Selatan. Bandung: PT. ATLAS.

Soemarto. (1987). Hidrologi Teknik. Surabaya: Usaha Nasional.

Triatmodjo, B. (2009). Perencanaan Pelabuhan. Yogyakarta: Beta Offset. 